\title{
A Multireligious Approach to the Integration of Migrants in Europe: An Examination of Migrants' Views on and Experiences of Taking Part in Multireligious Integration Projects
}

\author{
Majbritt Lyck-Bowen ${ }^{ \pm}$
}

\begin{abstract}
Violent conflicts continue to force many migrants to seek protection outside their own country. Some of these migrants have come to Europe, leading to states relying on assistance from civil society organisations, some of which are Faith-based Organisations (FBOs), to meet the migrants' complex needs. Whereas the important roles religious actors can play in integration processes have been increasingly addressed and acknowledged in the literature, multireligious cooperation on integration has yet to attract the same attention and recognition. Hence, in the first phase of the research project, A Multireligious Approach to Integration, a range of possible advantages of multireligious cooperation, from an organisational point of view, were identified. These included four benefits for the integration of migrants: 1) Understand and meet the religious/cultural needs of migrants; 2) Help migrants understand the roles of religion in their host community; 3) Counter the narrative that it is more important to help migrants from a particular religion and 4) Opportunity to meet the "other" and build relationships. Acknowledging that further research was needed, phase two has focused on migrants' opinions on, and experiences of, multireligious cooperation on integration. Data was collected via a survey and semi-structured interviews with migrants that have participated in multireligious projects in Germany, Sweden and the UK. In this article, the data is used to interrogate the organisational perspectives. The article concludes that in certain contexts multireligious cooperation has some distinctive benefits for the integration of migrants and calls for the further development of a multireligious approach to integration.
\end{abstract}

Keywords: multireligious; cooperation; migrant; integration; religious actors.

\section{Introduction}

In recent years, violent conflicts in especially parts of Africa and the Middle East have led to largescale protracted displacement. According to the International Organization for Migration there were 244 million migrants, more than 40 million internally displaced people and more than 22 million refugees around the world in 2018 (International Organization for Migration, 2018). Most of these migrants have taken refuge in the immediate regions, but some have also sought protection in Europe. In 2015, more than one million migrants crossed into Europe illegally, leading the media and many politicians to label the situation a "crisis" (BBC, 2015). In the European Union (EU), the arrival of the migrants led to political rifts between wealthier Northern European states such as Germany and Sweden, that initially welcomed the new arrivals and poorer Eastern European states such as Hungary, Slovakia and Poland that focused on fencing their borders and opposing EU plans

${ }^{ \pm}$Dr Majbritt Lyck-Bowen, Research Fellow and Programme Leader of MA in Reconciliation/Reconciliation and Peacebuilding, Winchester Centre of Religion, Reconciliation and Peace (WCRRP), Cemetery Cottage, The University of Winchester, United Kingdom. E-mail: Majbritt.Lyck-Bowen@winchester.ac.uk. 
on sharing the migrants between states (BBC, 2015). Though the number of migrants arriving to Europe has declined since 2015 (Henley, 2018), the issue of immigration has remained the main concern in the EU well ahead of the second main concern terrorism (European Commission, 2018) and a survey from 2016 suggested that attitudes towards immigration were perceived as having become more negative (IPSOS, 2016). The scale of the challenge of welcoming and integrating the many migrants with diverse needs, the limited resources of national institutions and the political sensitivities have led to European states relying on assistance from civil society organisations (Wilson and Mavelli, 2017). Some of the organisations, that states have depended on to help them address the migrants' short- and long-term needs, are Faith-Based Organisations (FBOs).

Whereas the significant roles religion and religious actors can play in integration processes have been increasingly addressed and recognised in the literature, multireligious cooperation on integration that is when actors from different religious backgrounds come together to help migrants, has yet to attract the same attention and acknowledgement (Lyck-Bowen and Owen, 2018). Hence, to address this gap in the literature, a research project named "A Multireligious Approach to Integration" was initiated in 2016, the first research carried out in this area. In phase one of this project, a wide range of possible advantages of multireligious cooperation from an organisational point of view were identified (Lyck-Bowen and Owen, 2018). Some of the benefits related to integration services and processes. The study identified the following four ways in which the organisations assessed migrants distinctively benefit from multireligious cooperation on integration: 1) Understand and meet the religious/cultural needs of migrants; 2) Help migrants understand the roles of religion in their host community; 3) Counter the narrative that it is more important to help migrants from a particular religion and 4) Opportunity to meet the "Other" and build relationships.

Acknowledging that further research was needed to support these initial findings, phase two of the research project focused on migrants' views on and experiences of multireligious cooperation on integration. Validating the findings of the first study by examining the views and experiences of migrants was considered important because as pointed out by Ives; Witmer and Cnaan (2010) thorough evaluations of local integration services are often scarce. Leurs (2012) has also rightfully argued that, 'Donors should be wary of funding FBOs rather than NGOs simply based on the formers' claims about their distinctiveness, especially as the evidence to permit systematic comparisons of their performance and effectiveness, to assess whether they possess the comparative advantages they often claim, is not yet available' (2012: 706). McKinnon (2009) has also justly contended that it is often taken for granted that migrants finds the assistance that local people and organisations provide helpful in their integration process without confirming this assumption with the migrants. Finally, a new survey by the European Migrant Advisory Board (2018) based on the views of more than 500 migrants and refugees from seven EU countries also showed that most respondents were dissatisfied with the integration services their host countries provided. Hence it was considered important to explore and examine the views and experiences of migrants that took/were taking part in the projects concerning these perceived benefits. This paper presents and discusses the findings from this research as it addresses the following research questions:

- To what degree if at all, do the migrants that take part in multireligious projects confirm the organisations' assessment of the distinctive benefits of taking part in multireligious projects for migrants?

- To what degree if at all are these distinctive benefits linked to the multireligious aspects of the integration projects? 
Since this is the first study of the opinions and experiences of migrants taking part in multireligious integration projects, there is no firm scholarly foundation for the development of hypotheses. The article concludes with a brief discussion of how the findings contribute to scholarship and practice and makes recommendations for further research.

\section{Definitions, Theories and Previous Studies}

Recognising the lack of a widely accepted definition of religion, but also the importance of having a working understanding of religion to research and debate in this area of study, the research adopted a wide and inclusive definition of religion that considered the multiplicity of contextual and cultural understandings of religion (Lyck-Bowen and Owen, 2018). Likewise, integration is also a widely contested term and a multifaceted phenomenon, which is reflected in the research' definition of the term since it defined integration as: 'the process by which people who are relatively new to a country become part of society' (Lyck-Bowen and Owen, 2018). These broad definitions allowed participants to apply their own understanding of religion and integration. This participatory approach palpably has some benefits as well as drawbacks.

One of the consequences of the complex and multifaceted nature of integration is that a single theory or model for successful integration is yet to be developed. Instead numerous scholars have developed a wide range of theoretical models attempting to capture successful integration (LyckBowen and Owen, 2018). Therefore, the theoretical framework for this research draws on several theories. Firstly, though it has also faced some criticism (see among others Garcia-Muñoz and Neuman, 2012 and Walseth, 2008) one of the most widely recognised models of integration in the literature is Putnam's theory of social capital (Putnam et al., 1993; Putnam, 2000; Putnam et al., 2004). The theory is based on the concepts of "bridging" that refers to actions aiming at building relationships between the migrant and people from the host community and "bonding" that refers to actions aiming at building relationships between the migrant and other people from the same ethnic/religious group. Putnam (2000) argued that both such networks are important for migrants' integration and he especially emphasized the significance of developing a network of local people for migrants to "get ahead" with integration. Since then "getting ahead" has especially been connected to finding employment and acquiring career progression (Ives et al., 2010; Walseth, 2008) but also more generally with access to important social resources (Lancee, 2010). Another theory that is relevant for this study is Allport's intergroup contact theory. According to Allport there are four main conditions for intergroup contact to reduce prejudice namely: 1) Both groups perceive equal status in the situation; 2) Common aims; 3) Intergroup cooperation and 4) Support of authority, law or custom (Pettigrew and Trapp, 2005). Though early reviews of the literature drew conflicting conclusions concerning the probable effects of intergroup contact a more recent review that included substantially more studies, concluded that intergroup contact usually diminishes prejudice (Pettigrew et al., 2011). Another relevant study has also drawn attention to the significance of cross-group friendships in aiding positive contact effects (Pettigrew and Tropp, 2006). ). In contrast, in his group threat theory Blalock (1967) has argued that an increase in an outgroup such as a group of migrants increases the local population's negative attitudes towards the group because the local population perceive them as a threat to their own interests.

The proposition that religion aids integration has been widely discussed in the broader postsecular debate in the literature (see: Ungureanu and Thomassen, 2015). Some authors such as Ghazal-Read (2004); Cadge and Ecklund (2006); Constant et al. (2006); Ramakrishnan and Viramontes (2006); and Van Tubergen and Sindradóttir (2011) have contested the notion that 


\section{A Multireligious Approach to the Integration of Migrants in Europe}

religion is helpful for integration arguing among others that religiosity is linked with less education and higher levels of unemployment. Foner and Alba (2008) and Garcia-Muñoz and Neuman (2012) have nuanced the debate by arguing that religion is seen as hindering the integration of migrants in Europe whereas it is seen as aiding the integration of migrants in the US. Garcia-Muñoz and Neuman (2012) suggested that religiosity can act as bridging factor if it facilitates contact between the local and migrant populations in accordance with the intergroup theory or as a buffer if it separates migrants from the local population in accordance with the group threat theory. Other authors such as Allen (2010); Connor and Koenig (2013); Gozdziak and Shandy (2002); Kirmani; Khan and Palmer (2008) and Mayer (2007) have defended the importance of identifying and meeting migrants' religious needs to aid their integration in a variety of ways including spiritual support and a sense of belonging. Though the support for religion playing an important role in the integration of migrants is still not unanimous, the focus seems to have shifted from whether religion has a role to play in integration, to under which circumstances and in which contexts religion can best aid the integration of migrants.

Secondly, part of the post-secular debate has also focused on the appropriateness of involving religious actors in integrating migrants. Initially religious organizations were perceived as lacking in skills, experience and professionalism and they were often, at times rightfully, suspected of only wanting to help people of their own faith or of proselytizing or promoting their faith to the people they were meant to help unconditionally (see Beaman et al., 2017; Heist and Cnaan, 2016; Lant, 2017; McKinnon, 2009; Wilson and Mavelli, 2017). In contrast, based on a study of FBOs involved in refugee resettlement in the US, Nawyn (2006: 1519 and 1522) contended that, 'staff sharing the religious beliefs of their organization understand resettlement as divinely mandated service, not an opportunity to practice religious rituals or spread their religious beliefs' and that 'when faith-based NGOs enacted religious practices, it was always to build community, not to proselytize'. The literature now also includes many examples of FBOs playing an active positive role in assisting migrants' integration by fore example helping with employment, economic opportunities, education and housing (Ebaugh and Chafetz, 2000; Foner and Alba, 2008; Ives et al., 2010; Mayda, 2010 and Portes, 1995) and by helping migrants get to know the main features of the host community such as its culture, traditions and the role of religion (Guest, 2003; Levitt, 2008). Ives et al's (2010), Kirmani; Khan and Palmer's (2008) and Gozdziak's (2002) studies have also shown that FBOs can help migrants with basic religious needs such as finding suitable places worship and shops selling religiously/culturally appropriate food and supporting migrants in practising their religion and celebrating their religious and cultural festivals. Relevantly, Allen (2010); Ives et al. (2010) and Portes (1995) have also argued that FBOs can help migrants in developing, strengthening and diversifying their social networks. Ives et al (2010: 86) even argued that 'congregations may best provide a network of relationships and friendships that most closely approximate the network of family and friends that a refugee has lost'. Relevantly for this study Allen (2010: 1052) has also maintained that: 'Immigrants who worship within multi-ethnic congregations may be particularly well-positioned to create out-group social networks that are helpful because of their diversity'. The multireligious aspects of the network is also especially important considering that in Kirmani et al (2008: 7) study of Islamic Relief's work with migrants it was asserted that 'as a result of a religious conflict, refugees may feel a heightened sense of affinity to their religion and distinctions between different religions (or factions of the same religion) may be exaggerated'. In addition, Kirmani et al (2008) also contended that organisations can exemplify interfaith cooperation by recruiting staff from different religious backgrounds. 
All these recent studies suggest that the focus in the literature is no longer mainly on whether FBOs generally should be involved in the process of integrating migrants but in which circumstances and contexts FBOs can make a positive contribution to the integration of migrants. Much of the literature has so far focused on how FBOs based on a specific religion help the integration of migrants belonging to the same religion. An example of this is Elliott and Yusuf (2014) study of a Somali community in New Zealand, that showed that the mosque helped the migrants bond. However, surprisingly few studies have explored the relationship between the religious affiliation of FBOs and the migrants they are trying to help, a relationship that Nawyn has rightfully called "a complicated one' (2006: 1510) in cases where they do not share the same religion, and how this influences the integration of migrants. The most noteworthy study is Allen's (2010: 1050) research on Christian Sudanese and Muslim Somali migrants living in a small American city which concluded: 'that in a non-gateway context, religious institutions affiliated with a minority religious tradition play a bonding role for refugees, while religious institutions affiliated with a majority religious tradition can play both a bonding and bridging role for refugees.' However, Nawyn's (2016: 1514) contention that 'we do not yet understand how the religion of the organization and the religion of the refugees served interact' still stands. This article aims to add another piece to this puzzle by being the first study that focuses on the benefits of multireligious cooperation on integration from migrants' point of view.

Based on the literature, this study assumes that addressing migrants' religious/cultural needs and exemplifying some of the roles, religion plays in the host communities, are important parts of aiding their integration. The social capital theory and the intergroup theory also support the assumption that some of the ways, projects can support the integration of migrants are by exemplifying and facilitating intergroup contact between the migrants and the local community and between different religious communities and by demonstrating that all groups are equally important.

\section{The Research Project}

\section{Summary of Phase One}

Phase one focused on the benefits of multireligious cooperation on integration from an organisational perspective. The case studies were purposively sampled based on the main criteria: 'two or more organisations representing different religious traditions had begun to cooperate on projects aiming to support the integration of migrants (Lyck-Bowen and Owen, 2018:5). Multireligious cooperation on integration is still rare, but after an intensive search, four projects were identified: a German project called Weisst Du Wer Ich bin?; a Polish project called Dialogue for Integration - a Multi-Faith Approach; a Swedish project named Goda Grannar and a UK-based project called Refugee Support. Data was collected through semi-structured interviews with representatives from the projects and organisations (Lyck-Bowen and Owen, 2018).

\section{Case Studies in Phase Two}

In addition to the criterion used in the first phase, the case studies used in the second phase also needed to have identifiable migrants that had taken part or were still taking part in the projects. The projects also needed to be continuing for more than a year since the research focuses on integration rather than merely welcoming migrants. The projects in Sweden and the UK fulfilled the criteria but the Polish project did not since it was not possible to identify the participants and hence it was excluded from the research. In the German case the original project was funding rather than running multireligious integration projects, so it was decided to include projects that had 
received funding. The research revealed that most of the projects were one-off events or short-term projects, but one project fulfilled both criteria and hence it was included in the study.

The German case study focused on an organisation called FlüBB - Flüchtlinghilfe Bad Berneck. This organisation is a nonpartisan and nondenominational citizens' initiative that was founded in September 2015 when a large group of refugees needing emergency shelter arrived in Bad Berneck ${ }^{1}$. Initially FlüBB focused on welcoming the migrants and providing food and shelter. However, now $F l \ddot{u} B B$ offers a wide range of services including help finding accommodation, organised sports activities and information about local services. The project is based in a small town that is predominantly Christian. A mosque in a nearby town supports the project, but because of the distance, the day-to-day running of the project is predominantly carried out by Christians.

The Swedish case study is a project called Goda Grannar (Good neighbours). This project was set up by a church (Svenska Kyrkan på Södermalm²), a mosque (Islamiska Förbundet Stockholm Moskè ${ }^{3}$ ) and Islamic Relief. Initially, the church and the mosque cooperated on meeting the immediate needs of the migrants but now the project offers a wide range of services including legal advice, information about local and national services, language classes, social events and sports activities ${ }^{4}$. The project is based in the middle of Stockholm in a religiously diverse area. The church and the mosque are equal partners and volunteers from both religious communities help run the project $^{5}$.

The project in the UK was called Refugee Support and it was led by the British Red Cross. Refugee Support offered practical and emotional support to asylum seekers and refugees from Syria to help them settle in their new communities ${ }^{6}$. The British Red Cross cooperated with local actors including some churches and a mosque ${ }^{7}$. However, since the mosque is situated in a different city from the city and surrounding towns, where the migrants have been placed. the day-to-day running of the project was mainly carried out by Christians.

\section{Research Methods and Methodology}

Based on the pragmatic research paradigm (see: Kivunja and Kuyini, 2017), the data collection encompassed two different methods, semi-structured interviews and a questionnaire. Semistructured interviews were chosen because they facilitated an assessment of the migrants' views on the four sets of potential benefits (Flick, 2015 and Waller et al, 2016). Once the interviews had been transcribed and translated into English, the data was analysed using codes to identify themes and patterns (Waller et al, 2016).

Time and financial constraints meant that not all migrants that were taking part in the projects could be interviewed and hence a questionnaire with questions designed to refute or substantiate the findings from the first study was also implemented. The questionnaire, that had been translated into the native languages of the migrants, also allowed for participants that did not want to be interviewed to be included in the study, and it facilitated a cautious check on the degree to which

\footnotetext{
${ }^{1}$ https://fluebb.jimdo.com/über-uns/

2 See: https://www.svenskakyrkan.se/katarina\#chlist-view=week\&chlist-today=2016-12-15T10\%3A20\%3A46. $000 Z \&$ chlist-selected $=2016-12-15 \mathrm{~T} 00 \% 3 \mathrm{~A} 00 \% 3 \mathrm{~A} 00.000 \mathrm{Z} \&$ chlist-pagination. top $=3 \&$ chlist-pagination. skip $=0 \&$ chlisttype $=$ date $\&$ chlist-filter $=$ day

${ }^{3}$ See: http://www.stockholmsmoske.se/

${ }^{4}$ https://www.facebook.com/groups/godagrannar/; http://www.unhcr.org/570bb0c16.html

${ }^{5}$ Interview with representatives from Goda Grannar, Stockholm December 2018.

${ }^{6} \mathrm{http}$ ://www.redcross.org.uk/What-we-do/Refugee-support/Our-services-for-refugees

${ }^{7}$ Interview with Red Cross representative, $18^{\text {th }}$ November 2016.
} 
the experiences and opinions of the migrants that did not want to be interviewed corresponded with those that did. Unfortunately, the number of migrants taking part in the projects during the time the fieldwork was carried out (November-December 2018 in Germany and Sweden and November 2018-March 2019 in the UK) was too small to warrant any more sophisticated statistical analyses. In the end, the data from the questionnaire was triangulated with the data from the interviews.

The recruitment process was very similar in the German and Swedish cases. In both cases, the interviewer took part in some of the projects' activities and kindly approached potential participants. Based on the snowballing approach, participants were also asked to identify other potential participants. In Sweden, 20 migrants were interviewed and 22 filled in the questionnaire whereas in Germany, 11 migrants were interviewed and 17 responded to the questionnaire. Though the exact number of migrants that took part in the German and Swedish projects during the time the fieldwork was carried out is not known, the interviewer and staff at the projects estimated that most of the participants took part in the research. No specific characteristics were identified in the small group of migrants that did not want to take part. In Germany and Sweden, the interviews were carried out by a female research assistant that had no prior engagement with the projects. The location of the interviews was chosen by the interviewee, most of them were carried out on the premises of the projects, but a couple took place in the home of the interviewees. Interviewees were assured that any criticisms of the projects would be welcomed since it would enrich the data and help improve the projects; that significant efforts would be made to anonymise the interview data and that taking part in the interviews would have no adverse effect on their continued participation in the projects. However, despite these initiatives, the context and the power imbalance still need to be considered in the interpretation of the findings. One of the ways they are addressed is through triangulation of the interview data with the more anonymous questionnaire data.

The recruitment strategy for the UK data collection differed from the other case studies for several reasons. Firstly, the UK-based project was only mandated to deal with refugees that were referred to them by local councils, which meant that fewer migrants took part. Secondly, because the project was no longer active, when the interviews and questionnaires were carried out, the identification of potential participants was significantly more difficult. Due to the alleged ${ }^{8}$ vulnerability of the refugees, the British Red Cross was not willing to share any records of the people, it had helped. Instead, the researcher contacted other integration projects in the area to identify potential participants. A higher proportion of UK participants preferred to fill in the questionnaire (13) rather than being interviewed (5). Based on email exchanges with the relevant councils, it is assumed that most migrant families were included in the study. The interviews were carried out by the lead researcher and they either took place in the homes of the interviewees or in a local café. Interviewees were assured that the data would be anonymised.

\section{Summary of Findings}

Before addressing the potential distinctive benefits of multireligious integration projects it is important to ascertain that the data from all three case studies showed that the projects were also able to meet the migrants' general needs such as providing them with food, clothes and housing, helping them find schools for their children and assisting them in accessing healthcare and learning the local language. The only area, where migrants from all three case studies would have liked to receive more general assistance, was with finding a job.

${ }^{8}$ I use the term "alleged" because I share McKinnon (2009)'s concern of constructing all refugees as "vulnerable" (p.320). 


\section{1) Understand and Meet the Religious/Cultural Needs of the Migrants}

The findings from the first phase showed that the organisations thought that because of their diverse religious backgrounds, they were more aware and better able to help migrants with basic religious needs such as finding suitable places of worship and shops selling religiously/culturally appropriate food, upholding religious rituals and celebrating religious festivals.

The Swedish interviewees had not received much help identifying places to shop and worship because the project is based close to the participating mosque and church and in a major diverse city, which meant that the migrants did not need any help with this. As demonstrated by this quote: 'It is good so that I see that there is a celebration that day even though I am not in my country, I go to Sweden and I see the celebration that day. It is very good when my children ask me: Why is it a celebration today? I can tell them about Ramadan and make them understand' most of the Swedish interviewees agreed that the project had helped them uphold their religious/cultural rituals and celebrate their religious/cultural festivals and that this was very important for them and their integration.

Table 1: To what degree do you agree with the following statement?

\begin{tabular}{|c|c|c|c|c|c|c|}
\hline Statement & Case & $\begin{array}{l}\text { Strongly } \\
\text { disagree }\end{array}$ & Disagree & $\begin{array}{c}\text { Neither } \\
\text { disagree nor } \\
\text { agree }\end{array}$ & Agree & $\begin{array}{c}\begin{array}{c}\text { Strongly } \\
\text { agree }\end{array} \\
\text { and }\end{array}$ \\
\hline \multirow{3}{*}{$\begin{array}{l}\text { Participating in Refugee } \\
\text { Support has helped me } \\
\text { continue to celebrate } \\
\text { religious events. }\end{array}$} & $\mathrm{G}$ & $5.9 \%(1)$ & 0 & $23.5 \%(4)$ & $23.5 \%(4)$ & $47.1 \%(8)$ \\
\hline & $\mathrm{S}$ & $4.5 \%(1)$ & 0 & $45.5 \%(10)$ & $45.5 \%(10)$ & $4.5 \%(1)$ \\
\hline & $\mathrm{U}$ & 0 & 0 & $9.1 \%(1)$ & $90.9 \%(10)$ & 0 \\
\hline \multirow{3}{*}{$\begin{array}{l}\text { - Participating in Refugee } \\
\text { Support has helped me } \\
\text { maintain my religious } \\
\text { rituals. }\end{array}$} & G & 0 & $5.9 \%(1)$ & $29.4 \%(5)$ & $29.4 \%(5)$ & $35.3 \%(6)$ \\
\hline & $\mathrm{S}$ & 0 & $9.1 \%(2)$ & $40.9 \%(9)$ & $45.5 \%(10)$ & $4.5 \%(1)$ \\
\hline & $\mathrm{U}$ & 0 & 0 & $10 \%(1)$ & $90 \%(9)$ & 0 \\
\hline
\end{tabular}

As illustrated by the following quotes most of the German and British interviewees had received help finding shops and places to worship upholding their religious rituals and celebrating their religious festivals: 'We have help to go to the supermarket, because it is possible we do not understand the food ... it is very nice, so we know, what food to eat'; 'They showed us where the mosque is ... and one of the Muslim people, he gave us like a rug and he showed us where is Qibla' and 'Once we were in Ramadan ... and they just took us from here to another city to make us manage to go and celebrate with them'. This help was considered important because their host communities were predominantly Christian and hence it was not easy to find places to shop and worship and communities to celebrate religious festivals with.

In addition, whereas the surveys from Germany and the UK generally supported the findings from the interviews, the survey data from Sweden was more ambivalent, since there were as many migrants neither disagreeing/agreeing as there were agreeing. The claim by one of the Swedish Christian interviewees that Goda Grannar celebrated Muslim festivals more than Christian festivals could potentially have explained this discrepancy but the claim was not supported in the rest of the data. Another possible explanation could be that because of the proximity of the church and the mosque, some migrants did not feel that they needed help from Goda Grannar to maintain their religious rituals and celebrate their religious festivals. 


\section{2) Help Migrants Understand the Roles of Religion in the Host Community}

Table 2: To what degree do you agree with the following statements?

\begin{tabular}{|c|c|c|c|c|c|c|}
\hline Statements & Case & $\begin{array}{l}\text { Strongly } \\
\text { disagree }\end{array}$ & $\begin{array}{c}\text { Dis- } \\
\text { agree }\end{array}$ & $\begin{array}{c}\text { Neither } \\
\text { disagree nor } \\
\text { agree }\end{array}$ & Agree & $\begin{array}{l}\text { Strongly } \\
\text { agree }\end{array}$ \\
\hline \multirow{3}{*}{$\begin{array}{l}\text { - Engaging with people } \\
\text { from different religions has } \\
\text { helped me understand the } \\
\text { role religion plays in my } \\
\text { host community. }\end{array}$} & $\mathrm{G}$ & 0 & 0 & $41.2 \%(7)$ & $41.2 \%(7)$ & $17.6 \%(3)$ \\
\hline & $\mathrm{S}$ & 0 & $4.8 \%(1)$ & $33.3 \%(7)$ & $38.1 \%(8)$ & $23.8 \%(5)$ \\
\hline & $\mathrm{U}$ & 0 & 0 & 0 & $90.9 \%(10)$ & $9.1 \% 1)$ \\
\hline \multirow{3}{*}{$\begin{array}{l}\text { - The cooperation between } \\
\text { organisations based on } \\
\text { different religions indicates } \\
\text { that inter-faith dialogue is } \\
\text { important in } \\
\text { Germany/Sweden/UK }\end{array}$} & $\mathrm{G}$ & 0 & 0 & $17.6 \%(3)$ & $35.3 \%(6)$ & $47.1 \%(8)$ \\
\hline & $\mathrm{S}$ & 0 & 0 & $13.6 \%(3)$ & $45.5 \%(10)$ & $40.9 \%(9)$ \\
\hline & $\mathrm{U}$ & 0 & 0 & $8.3 \%(1)$ & $66.7 \%(8)$ & $25 \%(3)$ \\
\hline \multirow{3}{*}{$\begin{array}{l}\text { - The cooperation between } \\
\text { organisations based on } \\
\text { different religions indicates } \\
\text { that people from different } \\
\text { religions can work together } \\
\text { in Germany/Sweden/UK. }\end{array}$} & $\mathrm{G}$ & 0 & 0 & $11.8 \%(2)$ & $35.3 \%(6)$ & $52.9 \%(9)$ \\
\hline & $\mathrm{S}$ & 0 & 0 & 0 & $54.5 \%(12)$ & $45.5 \%(10)$ \\
\hline & $\mathrm{U}$ & 0 & 0 & $10 \%(1)$ & $80 \%(8)$ & $10 \%(1)$ \\
\hline \multirow{3}{*}{$\begin{array}{l}\text { - The cooperation between } \\
\text { organisations based on } \\
\text { different religions indicates } \\
\text { that people from different } \\
\text { religions can socialise } \\
\text { together in the } \\
\text { Germany/Sweden/UK. }\end{array}$} & G & 0 & 0 & $17.6 \%(3)$ & $29.4 \%(5)$ & $52.9 \%(9)$ \\
\hline & $\mathrm{S}$ & 0 & 0 & $9.1 \%(2)$ & $40.9 \%(9)$ & $50 \%(11)$ \\
\hline & $\mathrm{U}$ & 0 & 0 & $10 \%(1)$ & $80 \%(8)$ & $10 \%(1)$ \\
\hline \multirow{3}{*}{$\begin{array}{l}\text { - Engaging with people } \\
\text { from different religions has } \\
\text { made me more accepting of } \\
\text { other faiths. }\end{array}$} & G & 0 & 0 & $29.4 \%(5)$ & $41.2 \%(7)$ & $29.4 \%(5)$ \\
\hline & $\mathrm{S}$ & 0 & $4.5 \%(1)$ & $28.6 \%(6)$ & $42.9 \%(9)$ & $23.8 \%(5)$ \\
\hline & $\mathrm{U}$ & 0 & 0 & $10 \%(1)$ & $90 \%(9)$ & 0 \\
\hline \multirow{3}{*}{$\begin{array}{l}\text { - The cooperation between } \\
\text { organisations based on } \\
\text { different religions indicates } \\
\text { that people are free to } \\
\text { practice their own religion } \\
\text { in Germany/Sweden/UK. }\end{array}$} & $\mathrm{G}$ & 0 & 0 & $11.8 \%(2)$ & $47.1 \%(8)$ & $41.2 \%(7)$ \\
\hline & $\mathrm{S}$ & 0 & 0 & $4.5 \%(1)$ & $45.5 \%(10)$ & $50 \%(11)$ \\
\hline & $\mathrm{U}$ & 0 & 0 & $10 \%(1)$ & $70 \%(7)$ & $20 \%(2)$ \\
\hline
\end{tabular}

Many of the interviewees from the first study argued that multireligious cooperation on integration can help migrants understand some of the important roles, religion play in the host community. This assumption was widely supported in the interviews and surveys in all three case studies though the surveys showed more support for some specific roles, religion plays rather than the roles of religion in general.

One of the aspects from the first study, was the assertion that multireligious cooperation showcases interfaith cooperation by showing that people from different religions can work together 
for a common aim. As illustrated by these quotes: 'It is a good role model that Muslims and Christians can cooperate' and 'I hope that it's the same thing even outside of Goda Grannar, that all people can cooperate even though they have different religions' support for this finding was most evident in the Swedish interview data. Noteworthily, as illustrated by this quote: 'Goda Grannar ... gives a very bright image when we talk about Muslims and Christians help each other and try to, support us, even though the majority of us are Muslims so it isn't something that, the image that exists in the Arab world or the Middle East about Christians' attitude towards Islam, the image that media focuses on' several interviewees also emphasised that they had changed their perception of possible relations between Christians and Muslims. Support for this finding was less evident in the German and UK interview data potentially reflecting that though people from different religions were involved in these projects, the day-to-day running of the projects was predominantly carried out by Christians. Still the survey data from all three case studies showed firm support for the assumptions that multireligious cooperation indicates that people from different religions can work together in the three countries.

Interviewees in the first study also contended that multireligious cooperation demonstrated that people from different religious background can socialise together and exchange information about each other's religious beliefs and practices. The interview and survey data from all three case studies confirmed this assumption. As exemplified by these quotes: 'They show that we can be together, you can marry anyone you want, you can live together, become friends' and 'I have friends and family and we are all happy even if we have different religions' most of the interviewees contended that the projects highlighted that people from different religious backgrounds can socialise and become friends. Many of the interviewees also argued that they were not used to interreligious interaction and relations before they settled in their host communities. An important exception to this were some of the UK migrants from Syria that argued that interreligious interaction and relations were common in Syria before the war. Many of the interviewees also contended that they had learnt a lot about other religious beliefs and practices through talking with other migrants and volunteers in the projects. Significantly and as illustrated by this quote: 'It has made me more open to other religious and to know how they are acting you know dealing with other religions' several of the interviewees from all three case studies also argued that talking with people from different religions had made them more positive towards other religions which was also confirmed in all three surveys.

Finally, the interviewees from the organisations also argued that their projects highlighted that there is freedom of religion in the host communities. This assumption was widely supported in the interviews and surveys from all three case studies. Many of the interviewees provided examples such as their beliefs not being questioned or criticised and being allowed to wear religious clothing and pray when they wanted as indicators of religious freedom. Interviewees from all three case studies also contended that taking part in the projects had helped them understand that in their host communities, people can follow a religion as much or as little as they want and that they were free to follow whatever school of thought within a religion they wanted as well. Furthermore, it had also helped them see that it was widely acceptable to change religion or not believe in any religion at all. Several interviewees also draw attention to the many differences between their new host communities and their homelands, where it was often argued that there were lots of rules and customs that prevented freedom of religious beliefs and practices. 


\section{3) Counter Narrative that it is more Important to Help Migrants from a Particular Religion}

Findings from the first phase showed that from an organisational point of view one of the distinctive features of multireligious cooperation on integration is that it helps counter the narrative that it is more important to help migrants belonging to the majority religion and/or the religion of the religious actor running the project.

Table 3: To what degree do you agree with the following statement?

\begin{tabular}{lcccccc}
\hline Statement & Case & $\begin{array}{l}\text { Strongly } \\
\text { disagree }\end{array}$ & Disagree & $\begin{array}{c}\text { Neither } \\
\text { disagree } \\
\text { nor agree }\end{array}$ & Agree & $\begin{array}{c}\text { Strongly } \\
\text { agree }\end{array}$ \\
\hline $\begin{array}{l}\text { - The cooperation between } \\
\text { people from different } \\
\text { religions helps counter the }\end{array}$ & $\mathrm{G}$ & $11.8 \%(2)$ & $23.5 \%(4)$ & $17.6 \%(3)$ & $29.4 \%(5)$ & $17.6 \%(3)$ \\
\cline { 2 - 7 } $\begin{array}{l}\text { narrative that it is more } \\
\text { important to help migrants } \\
\text { from a particular religion } \\
\text { than other migrants. }\end{array}$ & $\mathrm{S}$ & $4.5 \%(1)$ & $9.1 \%(2)$ & $13.6 \%(3)$ & $45.5 \%(10)$ & $27.3 \%(6)$ \\
\hline
\end{tabular}

The findings from the three case studies generally supported the findings from the first study, but there were also some noteworthy nuances. Whereas the interview data from Germany clearly showed that the interviewees felt that the project had treated them all equally, the survey data from Germany was more ambiguous, since only a small majority agreed that, 'the cooperation between people from different religions helps counter the narrative that it is more important to help migrants from a particular religion than other migrants'. More research is needed to explain this apparent discrepancy between the two types of data that underlines the importance of using mixed methods to get a fuller insight into migrants' opinions and experiences. As illustrated by these quotes: 'They gather all the religions and gave the thought there is no difference between the religions' and 'First of all, how they treat people, like they help in an unconditional way' the findings from the Swedish interviews and survey supported the notion that multireligious cooperation helps migrants feel that they all receive the assistance they need, regardless of their religious affiliation. However, as demonstrated by this quote from a Muslim migrant: 'The Christians who came from Syria they feel that this country is their country more than I feel that this country is my country' there was one noteworthy exception.

Most of the interviewees and the survey respondents from the UK confirmed that taking part in the multireligious project had made them feel that Muslims were treated equally to Christians in the UK, focusing more on general acceptance because the migrants taking part in the project were predominantly Muslim. As exemplified by this quote: 'They are treating you like a human being not like it is depending on your religion. So, you know that is what I like about them before I came here I was worried about those things but when I first came here and met these people all these worries disappeared and when I feel like they are treating me like a human being and giving me a hand' a couple of the interviewees admitted to having feared that as Muslims they would not be easily accepted in the predominantly Christian UK, but these perceptions had changed, when they were met by Christians offering to help them settle. In contrast, another interviewee argued that he was used to helping migrants from different backgrounds in Syria and hence he anticipated that people from different religious backgrounds would also help him. 
Interestingly, many of the interviewees, from all three case studies, described how they had taken part in celebrations and events based on other religions, but none of them saw this as an attempt to proselytise. However, a couple of the Swedish interviewees also highlighted that they knew other migrants that did not want to participate in the project, because of the involvement of the church and the perceived risk of being persuaded/required to change their religion.

\section{4) Opportunity to Meet the "Other" and Build Relationships}

Finally, representatives from the organisations running the multireligious projects also argued that the projects offered migrants and local people an opportunity to meet the "other" and build relationships and diverse networks. This assumption was supported in the German and UK cases but only partly in the Swedish case. In all three case studies interviewees contended that especially parties and outings had helped them meet local people. In accordance with the intergroup contact theory, some of the Swedish interviewees also emphasised the importance of local people meeting the migrants to break down barriers between them as indicated in this quote: 'Every human who is a newcomer has a, let's assume, wrong idea about the other side, and on the other hand, the native ... citizens also have a wrong idea about the people who are new here, us. These organizations help breaking this ice or the barrier of fear, like, this is really good.'

Table 4: To what degree do you agree with the following statements?

\begin{tabular}{|c|c|c|c|c|c|c|}
\hline Statements & Case & $\begin{array}{l}\text { Strongly } \\
\text { disagree }\end{array}$ & Disagree & $\begin{array}{c}\text { Neither } \\
\text { disagree } \\
\text { nor agree }\end{array}$ & Agree & $\begin{array}{c}\text { Strongly } \\
\text { agree }\end{array}$ \\
\hline \multirow{3}{*}{$\begin{array}{l}\text { - Participating in the } \\
\text { project has helped me } \\
\text { make friends outside } \\
\text { my own ethnic group. }\end{array}$} & G & 0 & 0 & $5.9 \%(1)$ & $35.3 \%(6)$ & $58.8 \%(10)$ \\
\hline & $\mathrm{S}$ & 0 & $5 \%(1)$ & $20 \%(4)$ & $45 \%(9)$ & $30 \%(6)$ \\
\hline & $\mathrm{U}$ & 0 & 0 & 0 & $90 \%(9)$ & $10 \%(1)$ \\
\hline \multirow{3}{*}{$\begin{array}{l}\text { - Participating in the } \\
\text { project has helped me } \\
\text { build a network outside } \\
\text { my own ethnic group. }\end{array}$} & G & 0 & $5.9 \%(1)$ & $5.9 \%(1)$ & $17.6 \%(3)$ & $70.6 \%(12)$ \\
\hline & $\mathrm{S}$ & 0 & $9.5 \%(2)$ & $9.5 \%(2)$ & $52.4 \%(11)$ & $28.6 \%(6)$ \\
\hline & $\mathrm{U}$ & 0 & 0 & 0 & $90 \%(9)$ & $10 \%(1)$ \\
\hline
\end{tabular}

Many interviewees and survey respondents from all three case studies also confirmed that taking part in the multireligious integration projects had helped them make friends outside their own religious/ethnic group and several interviewees contended that some of the people they had met through the projects had become like family to them.

However, and significantly, a minority of interviewees and survey respondents from especially Sweden also contended that taking part in the project had not helped them make friends with any local people. Several of the Swedish interviewees highlighted that though they had met some local people through the project, the relations had not developed into friendships outside the project. Goda Grannar has addressed this by setting up a friendship family programme that pairs local families with a migrant family, ${ }^{9}$ but some of the migrants pointed out that the waiting list was long and hence they had not been allocated a local family yet. In Germany and the UK only one

\footnotetext{
${ }^{9}$ Interview with representatives from Goda Grannar $11^{\text {th }}$ December 2018.
} 
interviewee reported that they had not managed to build friendships and networks outside their own group.

\section{Discussion of Findings:}

To What Degree if at all, Do Migrants Confirm the Distinctive Benefits of Taking Part in Multireligious Integration Projects and To What Degree are the Benefits Distinctive?

The findings from this study generally confirmed the benefits of multireligious cooperation that the organisations had identified to a high degree, though there were also some noteworthy variations.

Concerning the first benefit, most of the migrants from the three projects contended that the projects had understood and met their religious/cultural needs and that this was important for their integration supporting the assertion in the literature that addressing the religious/cultural needs of migrants is important for their integration. Since the context was different in the Swedish case, the help the migrants had received was less extensive than the help the migrants had received in Germany and the UK. Though none of the interviewees directly linked the fulfilment of their religious/cultural needs with the multireligious cooperation several interviewees from all three case studies implied that the multireligious aspect had made a difference since it meant the projects had a deeper understanding and respect of all the migrants' religious/cultural needs regardless of what religion the migrants belonged to as indicated in these quotes from Christian and Muslim interviewees: 'Because they respect everyone's religion not just Christians or Muslims'; 'They respect each other and don't want to put anyone's faith down'; 'They show respect, they know all traditions, so they respect us'; 'When there is like, our religious celebrations, they participate in them with us, this is a very nice thing' and 'They are really sensitive to our religion, they are really interested to know more about us'. It is also noteworthy that most of the migrants regardless of whether they considered themselves to be Christians or Muslims contended that the projects had fulfilled their religious/cultural needs indicating that multireligious project are able to help migrants from both minority and majority religions in this area.

In addition, most of the migrants agreed that the projects had helped them understand some of the roles, religion play in their new community through among others exemplifying interreligious relationships and that this was important for their integration in accordance with the social capital and intergroup contact theories. The interviewees from all three case studies provided numerous examples of how the projects had exemplified that people with different religious backgrounds can work and socialise together and how there is freedom of religious belief and practice in their host communities. These examples included: 'Helped me understand better that all religions can be together with no problem'; 'It is important that we all see the different types of religions and to learn about one another's tradition. Here I know they are open to all kinds of religions which is helpful for integration'; 'I have Muslim friends, Christian friends and even friends who don't believe in anything. They are all still my friends. Religion shouldn't come in between friendships' and 'It is a good role model that Muslims and Christians can cooperate'.

Furthermore, in addition to confirming that multireligious cooperation can help counter the narrative that it is more important to help migrants from a specific religion, interviewees also argued that participating in the projects had changed their perceptions of the host community's attitudes to other religions and had made them feel equal regardless of their diverse backgrounds, which had helped making them feel welcome and aided their integration in accordance with the intergroup contact theory. As the following quotes from the interview data illustrate many of the interviewees 


\section{A Multireligious Approach to the Integration of Migrants in Europe}

from all three projects linked the third set of benefits with the multireligious cooperation: 'Made me have a new family with Muslims and other Christians'; 'Having all religions is better than to have one religious organisation'; 'They gather all the religions and gave the thought there is no difference between the religions'; 'I think that it (referring to multireligious cooperation) shows that Sweden consider all people the same, regardless if you are Christian or Muslim, that doesn't matter for Sweden. Everyone is equal here' and 'Like, it is a family, one family. Like you feel that all of them is one family, really they do not make any difference based on religion, there is no difference'.

Most participants in both the surveys and the interviews confirmed that the participants had managed to make friends and build a network outside their own religious/cultural group that included local people, emphasising that in these cases religiosity had acted as a bridge in accordance with the intergroup contact theory rather than as a buffer in accordance with the group threat theory. Numerous interviewees from especially Sweden but also Germany and the UK also linked making friends and developing a network outside their own ethnic/religious group with improved opportunities to learn the language, get to know the local culture and customs, gain employment and generally integrate in accordance with the literature on social capital theory. As illustrated in these quotes, many of the interviewees from all three projects emphasised the importance of meeting people from different religions through the projects and developing a diverse network in accordance with Allen's (2010) assertion: 'I don't only have Christian friends ... I know more people with different religions as me and we are friends'; 'I think that a cooperation between different religions in different organizations is really good and it brings people closer, especially those who are from different countries and have different backgrounds' and 'I have a lot of Christians friends now I have a Jewish friend and I have new Muslim friends, so I am really happy to be surrounded by all those people' indicating the significance of the multireligious aspect of the projects.

However, as illustrated by this quote: 'I've met friends from other religions, Arabs for example, but I haven't met any Swedish friends' a significant minority of the Swedish interviewees also contended that though they had made friends with people from their own religious/cultural group through the project, they would have liked to build a more extensive network including more local people. More research is needed to determine whether this difference is project or context related or a combination of both. One of the UK interviewees suggested a contextual factor that could help explain the difference, since she contended that she had had to make friends with people outside her own group, because her family was the only family from her own group in the town, where they had settled. The same was the case for migrants taking part in the German project whereas the Swedish project was based in a multicultural city with a diverse population. One of the Swedish interviewees also admitted that: 'They have helped to build a social network on some level. In the end I also have to choose who I talk to and make contacts with' highlighting the importance of personal efforts and commitment needed to develop friendships regardless of the opportunities offered by the project. Hence, based on this study it is more plausible to conclude that one of the benefits of multireligious cooperation on integration is that such projects provide migrants with better opportunities to meet and develop diverse friendships and networks outside their own religious/cultural group, but that other contextual and personal factors determine what migrants make of these opportunities.

\section{Limitations}

Before discussing the significance of the findings for scholarship and practice it is important to address the main limitations to the study. 
Firstly, the reliance on three case studies from Northern Europe necessarily raises important questions about the study's generalisability. As it has been pointed out by among other Leurs (2012) the context in which organisations operate has a significant impact on the organisations in many ways, including the ways in which religion can influence their activities. Sweden, Germany and the UK are all states with a high degree of religious freedom that facilitates multireligious cooperation, and the findings should only be cautiously extrapolated to similar states and not generalised to states with more conservative and restrictive views on religion and very different approaches to integration. The study also emphasised the influence of the local context (fore example the geographical distance between the mosque and the Muslim community) on the projects and hence generalising the findings from one setting to another within the same country should be done carefully and include reflections on the significance of contextual factors.

Secondly, this study also solely focused on cooperation between Christian and Muslim religious actors and as it has been highlighted by among others Allen (2010) this necessarily raises important questions about the generalisability of the findings of the study to other religions. Furthermore, this study also only includes Muslim and Christian migrants and hence it cannot meaningfully claim anything about the benefits migrants from other religions get from taking part in such projects.

\section{Conclusion}

Keeping these limitations in mind, the second phase of this research project has made important contributions to our understanding of the potential distinctive benefits of a multireligious approach to integration.

Firstly, at a time when many countries are struggling to integrate migrants and when many migrants are unhappy with the integration services they receive (European Migrant Advisory Board, 2018 ) it is important to explore new innovative ways of delivering integration projects. This study makes an important contribution to the development of practices in this area, since it confirms that in certain contexts, there are many ways in which participating in a multireligious project help migrants integrate into their host community. However, the study also revealed that a significant minority of the Swedish interviewees had not managed to build a social network outside their own religious/ethnic group. Bearing in mind the amount of literature on social capital theory and intergroup contact theory that considers these social networks as very important for migrants' integration, this is a significant finding. Goda Grannar has already addressed this shortfall by establishing a friendship family programme and it will be interesting to see the degree to which this initiative will help migrants make friends and networks outside their own religious/ethnic group. However, more research is also needed to determine, how contextual factors such as personality and language skills influence migrants' ability to develop social networks outside their own group and hence also how integration projects can help build these networks to aid integration. Furthermore, the differences between the migrants' experiences in the Swedish project and the German/UK projects cautiously support Allen's (2010) finding that the bridging roles of religious organisations for migrants differ depending on whether the projects are based in a gateway or nongateway context. More research is needed to confirm this premonition.

Secondly, in terms of scholarship and further development of a post-secular approach to integration, the findings support the assumption in the literature that religion can play an important role in the integration process. However, the study makes a more significant contribution to the debate on who should be involved in the integration of migrants. So far, the post-secular literature 


\section{A Multireligious Approach to the Integration of Migrants in Europe}

has focused on how and in which contexts and under which circumstances FBO's based on a single religion can contribute to the integration of migrants. However, the findings from this study suggest that there are at least four distinctive and significant ways in which FBOs can contribute further to the integration of migrants if they work together with other FBOs representing a different religion. This supports the importance of developing a multireligious theory on integration that stresses the importance of involving two or more FBOs representing different religions in the integration process rather than relying on integration projects run by a single FBO, which is currently the norm in the literature. The findings from this study supports the inclusion of project-based factors (such as the degree to which the FBOs are equal partners in the implementation of the project) as well as contextual factors (such as the distance between the location where the migrants have been settled to their nearest religious community and place of worship) in such a theory. Though this research has taken an important first step, a lot more research is needed to gain a comprehensive understanding of all the project and context related variables that influence the achievements of multireligious integration projects. The intricate relationship between the religions of the participating organisations and the migrants also need to be further explored. This research has also stressed the importance of including the views and experiences of migrants and of using different research methods to capture as many perspectives as possible.

Considering the scope of the challenge of successfully integrating migrants from many backgrounds into their new communities and the limited resources available to address this challenge, it is important that we continue to expand and deepen our understanding of which integration services and processes are most effective. More research is needed that considers how local and national contexts influence integration services and processes and which actors should be involved in developing and implementing these projects. It is also essential that this research includes migrants' perspectives. Though Leurs (2012) has warned that the distinctiveness of FBOs should not be taken for granted and that Nawyn's (2006) study has shown that there are more similarities than differences in the way secular organisations and FBOs help settle migrants, the emerging post-secular approach to integration calls for the inclusion of FBOs in research that focuses on how best to ensure the integration of migrants (Ager and Ager 2017). This research has made a compelling case for not only focusing on mono-religious integration projects and processes but also including multireligious integration projects and processes in such deliberations.

\section{References}

Ager, A. and Ager, J. (2017). "Challenging the Discourse on Religion, Secularism and Displacement”. In: L. Mavelli and E.K. Wilson (eds.) The Refugee Crisis and Religion, London: Rowman and Littlefield International.

Allen, R. (2010). "The bonding and bridging roles of religious institutions for refugees in a non-gateway context". Ethnic and Racial Studies 33(6): 1049-1068. DOI: 10.1080/01419870903118130.

BBC (2015). "Migrant crisis: One million enter Europe in 2015". https://www.bbc.co.uk/news/world-europe35158769 .

Beaman, L. G; Selby, J.A. and Barras, A. (2017). "No Mosque, No Refugees: Some Reflections on Syrian Refugees and the Construction of Religion in Canada". In: L. Mavelli and E.K. Wilson (eds.) The Refugee Crisis and Religion, London: Rowman and Littlefield International.

Blalock Jr, H.M. (1967). Toward a Theory of Minority-group Relations. Capricorn Books, New York.

Cadge, W. and Ecklund, E.H. (2006). "Religious Service Attendance among Immigrants: Evidence from the New Immigrant Survey-Pilot". American Behavioral Scientist 49 (11): 1574-1595. doi:10.1177/0002764206288455.

Connor, P. and Koenig, M. (2013). "Bridges and Barriers: Religion and Immigrant Occupational Attainment across Integration Contexts”. International Migration Review 47(1): 3-38. https://doi.org/10.1111/imre.12012|. 
Constant, A.; Gataullina, L; Zimmermann, K.F. and Zimmermann, L. (2006). "Clash of Cultures: Muslims and Christians in the Ethnosizing Process". IZA Discussion Paper No. 2350. http://ftp.iza.org/dp2350.pdf.

Ebaugh, H. R. and Chafetz, J.S. (2000). Religion and the new immigrants: Continuities and adaptations in immigrant congregations. Walnut Creek, CA: Altamira Press.

Elliott, S. and Yusuf, I. (2014). "“Yes, we can; but together': social capital and refugee resettlement". New Zealand Journal of Social Sciences Online 9(2): 101-110. DOI:10.1080/1177083X.2014.951662.

European Commission (2018). "Autumn 2018 Standard Eurobarometer: Positive image of the EU prevails ahead of the European Elections". http://europa.eu/rapid/press-release IP-18-6896 en.htm.

European Migrant Advisory Board (2018). "Ask the People - $\bar{A}$ consultation of migrants and refugees". https://ec.europa.eu/migrant-integration/librarydoc/ask-the-people-a-consultation-of-migrants-and-refugees.

Eurostat (2018). "Migrant integration statistics - labour market indicators". https://ec.europa.eu/eurostat/ statisticsexplained/index.php/Migrant_integration_statistics_\%E2\%80\%93_labour_market_indicators\#Une mployment.

Flick, U. (2015). Introducing Research Methodology. London: SAGE Publications Ltd.

Foner, N. and Alba, R. (2008). "Immigrant Religion in the U.S. and Western Europe: Bridge or Barrier to Inclusion?”. International Migration Review 42 (2): 360-392. doi:10.1111/j.1747-7379.2008.00128.x.

García-Muñoz, T. and Neuman, S. (2012). "Is Religiosity of Immigrants a Bridge or a Buffer in the Process of Integration? A Comparative Study of Europe and the United States". IZA Discussion Paper No. 6384. http://ftp.iza.org/dp6384.pdf.

Ghazal-Read, J. (2004). "Cultural Influences on Immigrant Women's Labor Force Participation: The ArabAmerican Case". International Migration Review 38(1): 52-77. doi:10.1111/j.1747-7379.2004.tb00188.x.

Gozdziak, E.M. (2002). "Spiritual Emergency Room: The Role of Spirituality and Religion in the Resettlement of Kosovar Albanian". Journal of Refugee Studies 15(2): 136-152. https://doi.org/10.1093/jrs/15.2.136.

Gozdziak, E.M. and Shandy, D.J. (2002). "Editorial Introduction: Religion and Spirituality in Forced Migration". Journal of Refugee Studies 15(2): 129-135. https://doi.org/10.1093/jrs/15.2.129.

Guest, K. J. (2003). God in Chinatown: Religion and Survival in New York's Evolving Immigrant Community. New York: New York University Press.

Henley, J. (2018). "What is the current state of the migration crisis in Europe?". The Guardian. https:/www.theguardian.com/world/2018/jun/15/what-current-scale-migration-crisis-europe-future-outlook.

International Organization for Migration (2018). "World Migration Report 2018". https://www.iom.int/wmr/worldmigration-report-2018.

IPSOS (2016). "Change in Attitudes towards Immigrants". IPSOS Global Trends. https://www.ipsosglobaltrends. com/change-in-attitudes-towards-immigrants- $2 /$.

Ives, N.; Sinha, J.W. and Cnaan, R. (2010). "Who Is Welcoming the Stranger? Exploring Faith-Based Service Provision to Refugees in Philadelphia". Journal of Religion \& Spirituality in Social Work: Social Thought 29(1): 71-89. DOI:10.1080/15426430903479270.

Kirmani, N.; Khan, A.A. and Palmer. V. (2008). "Does Faith Matter: An Examination of Islamic Relief's Work with Refugees and Internally Displaced Persons". Refugee Survey Quarterly 27(2): 41-50. DOI: $10.1093 / \mathrm{rsq} / \mathrm{hdn} 032$.

Kivunja, C. and Kuyini, A.B. (2017). "Understanding and Applying Research Paradigms in Educational Context". International Journal of Higher Education 6(5): 26-41. DOI:10.5430/ijhe.v6n5p26.

Lancee, B. (2010). "The Economic Returns of Immigrants' Bonding and Bridging Social Capital: The Case of the Netherlands". International Migration Review 44(1): 202-226. DOI: 10.1111/j.1747-7379.2009.00803.x.

Lant, B. (2017). "Praxis Community Projects: A Secular Organization? Exploring the Boundaries Between Religious and Secular in Migration Support". In: L. Mavelli and E.K. Wilson (eds.) The Refugee Crisis and Religion, London: Rowman and Littlefield International.

Leurs, R. (2012). "Are FBOs distinctive? Comparing religious and secular NGOs in Nigeria". Development in Practice, 22(5-6): 704-720, DOI:10.1080/09614524.2012.685868.

Mayda, A. M. (2010). "International Migration: A Panel Data Analysis of the Determinants of Bilateral Flows". Journal of Population Economics 23 (4): 1249-1274. http://www.jstor.org/stable/40925859.

Mayer, J. F. (2007). "Introduction: "In God have I put my trust": refugees and religion". Refugee Survey Quarterly 26(2): 6-10. https://doi.org/10.1093/rsq/hdi0222. 
McKinnon, S.L. (2009). ““Bringing New Hope and New Life”: The Rhetoric of Faith-Based Refugee Resettlement Agencies". The Howard Journal of Communications 20(4): 313-332. DOI: 10.1080/10646170903300747.

Lyck-Bowen, M. and Owen, M. (2018). A multi-religious response to the migrant crisis in Europe: A preliminary examination of potential benefits of multi-religious cooperation on the integration of migrants. Journal of Ethnic and Migration Studies, DOI:10.1080/1369183X.2018.1437344.

Nawyn, S.J. (2006). "Faith, Ethnicity, and Culture in Refugee Resettlement". American Behavioral Scientist 49(11): 1509-1527. DOI: https://doi.org/10.1177/0002764206288462.

Pettigrew, T.F. and Tropp, L.R. (2005). "Allport's Intergroup Contact Hypothesis: Its History and Influence”. In J.F. Dovidio; Glick, P. and Rudman, L.A. (eds.) On the Nature of Prejudice; Fifty Years after Allport, Oxford: Blackwell Publishing.

Pettigrew, T.F and Tropp, L.R. (2006). “A meta-analytic test of intergroup contact theory”. Journal of Personality and Social Psychology, 90(5): 751-783. http://dx.doi.org/10.1037/0022-3514.90.5.751

Pettigrew, T.F.; Tropp, L.R.; Wagner, U. and Christ, O. (2011). "Recent Advance in Intergroup Contact Theory". International Journal of Intercultural Relations, 35(3): 271-280. https://doi.org/10.1016/j.ijintrel. 2011.03 .001

Portes, A. (1995). "Economic sociology and the sociology of immigration.” In A. Portes (eds.) Economic Sociology of Immigration, New York: Russell Sage Foundation.

Putnam, R. D. (2000). Bowling alone. The collapse and revival of American community. New York: Simon \& Schuster.

Putnam, R. D.; Feldstein, L.M. and Cohen, D. (2004). Better together. Restoring the American Community. New York: Simon \& Schuster Paperbacks.

Ramakrishnan, S. K., and Viramontes, C. (2006). Civic Inequalities: Immigrants Volunteerism and Community Organizations in California. San Francisco: Public Policy Institute of California. http://www.ppic.org/ content/pubs/report/R_706KRR.pdf.

Ungureanu, C and Thomassen, L. (2015). “The Post-secular Debate: Introductory Remark”. The European Legacy, 20(2): 103-108, DOI: 10.1080/10848770.2015.1006928

Van Tubergen, F. and Sindradóttir, J. (2011). "The Religiosity of Immigrants in Europe: A Cross-National Study". Journal for the Scientific Study of Religion 50 (2): 272-288.

Waller, V.; Farquharson, K. and Dempsey, D. (2016). Qualitative Social Research. London: SAGE Publications Ltd.

Walseth, K. (2008). "Bridging and bonding social capital in sport—experiences of young women with an immigrant background". Sport, Education and Society. 13(1): 1-17. DOI: 10.1080/13573320701780498.

Wilson, E. K., and Mavelli, L. (2017). "The Refugees Crisis and Religion: Beyond Conceptual and Physical Boundaries". In: L. Mavelli and E.K. Wilson (eds.) The Refugee Crisis and Religion, London: Rowman and Littlefield International. 